\title{
Subverting the Ethics of Crime Fiction in Dževad Karahasan's Noćno vijeće (The Night Council)
}

\author{
Matija Bosnjak*
}

\begin{abstract}
This article explores the crisis of modernity using the example of Dževad Karahasan's novel Noćno vijece (The Night Council), a work of literature thematising war crimes committed in the name of nationalism during the 1990s in Yugoslavia. By comparing the specific compositional features of this novel with the general formal and ideological tendencies of crime fiction as such, our analysis establishes that the ethical foundations of contemporary civilisation along with the modern notion of justice as mirrored by the genre of the detective novel are, in the case of Noćno vijeće (The Night Council), treated as questionable. Belonging to the line of critique that observes modernity as a state of permanent crisis, this novel betrays the standard conventions of the criminalist genre, thereby contesting the modern era's prevalent idea of justice by reflecting on the complexity of ethical order in human society.
\end{abstract}

Key words: The Night Council, Detective novel, Crime Fiction, Nationalism, Rationality, Modernity, Justice, Ethics

\footnotetext{
* University of Sarajevo, Bosnia and Herzegovina; matija.bosnjak@hotmail.com
} 
Despite being composed according to several conventions of a detective novel, with the main protagonist compelled to prove his innocence regarding a series of puzzling murders that took place after his homecoming in the town of Foča, there are yet several indications that Dževad Karahasan's novel Noćno vijeće (The Night Council) can be interpreted as a piece of literature that deals with what might be defined as the crisis of modernity. This novel, initially published in the year 2009, received a substantial amount of critical attention both in Bosnia and Herzegovina and in German-speaking countries, although the reactions strongly differed when it came to evaluating its cultural relevance. Certain critics have attempted to proclaim Noćno vijeće a novel likewise contaminated with nationalism based on an 'anti-Serbian' sentiment for the way it treated the topic of war crimes committed in the name of Serbian nationalism, whereas the interpretative possibility, namely, that nationalist ideologies of the 1990s in Yugoslavia were taken as a mere symptom of a more fundamental rupture in our modern age, was largely neglected, if not tendentiously excluded in advance. It is by no means incidental that this novel's cultural value was questioned on ethical grounds, nor does the explanation that a sort of ethical debate was raised solely because of the author's choice to embark on such a sensitive topic appear satisfying. Only a thorough reading may reveal that the core issue confronted by this piece of literature is, in fact, of an ethical nature, and, moreover, that these issues are seen as a consequence of modernity as such. Furthermore, this can also provide an argument for understanding Noćno vijece as a novel that reflects the impossibility of resolving fundamental ethical problems within the realm of modern reasoning, including both the modern political and juridical value systems.

First of all, a concise outline of the novel's plot is needed so that its genre-specific structural features and varieties of the literary motifs it employs can be analysed in light of this broader ethical topic. Noćno vijece begins with the main hero named Simon arriving at his hometown Foča (Bosnia and Herzegovina) after a yearlong period of absence spent in Berlin. The year of his homecoming, 1991, is wisely chosen for the temporal framework of the story, since it is the year when the war started in Croatia, indicating clearly that Yugoslavia will not be able to disintegrate without violent conflict. What is also important to notice, right at the beginning, is that this choice of initial narrative situation - the homecoming of the main protagonist - appears frequently in the literature of $20^{\text {th }}$ century modernism, and thereby can be considered as a somewhat typical modernist literary motif, especially in the case of the so-called Trümmerliteratur which developed during the aftermath of World War II, thus thematising the alienation of individuals in a society incapable of rejuvenating itself after a political or moral catastrophe. Later on, this motif will become frequently exploited in the so-called Anti-Heimatliteratur, written in Austria during the second half of the $20^{\text {th }}$ century to this day. In any case, what 
is so modernist about the "heimkehr-motif" is the position of the individual in relation to the society of their belonging: neither feeling at home nor a complete stranger, the main protagonist occupies a paradoxical position, making him both suspicious (from the society's point of view) and a sceptic (from his own perspective) at the same time. This is exactly how Simon, the main character in Noćno vijece, behaves and is, again, treated by his fellow citizens. What complicates his situation further is the fact that the same night he arrives in Foča, a woman is found raped and murdered in the vicinity of her house and, to make matters even worse, that this woman was his high school girlfriend and that he got into a fight with a drunkard who also used to be in love with this woman in the past. The fight between the two ends with Simon being taken to the police station for interrogation, where his former high school teacher, now a police officer, Mirko Landeka, explains to him that since the night of the murder, the only thing that had changed in Foča was his arrival, which made him (according to logical reasoning) a probable suspect. Landeka concludes his report by convincing Simon that he has nothing to worry about because he is "one of them", meaning he is s Serb. Nevertheless, his passport will be taken away until further notice. A couple of nights later, another murder takes place with all circumstances again pointing at Simon, since the victim was the drunkard with whom he had been caught up in a bar-fight. Finally, after the third and the fourth murder happening in Foča, it becomes obvious that all of the victims essentially have two things in common: they are all somehow connected to Simon, and, secondly (but no less significantly), they are all Muslims, that is, people of Bosniak ethnicity, which seems to reveal nationalist hatred as the core motivation for committing these crimes.

In Stanko Lasić's Poetika kriminalistickog romana (The Poetics of a Detective Novel), presumably the most exhaustive study written about this particular genre in the context of Yugoslavian literary theory, one can find a useful typology of crime stories based on differentiating the main character's relation towards the enigma of the committed crime, which can be taken, as argued by the author of the study, as general foundation of the crime genre as such: "I am undertaking the analysis of the detective novel with a hypothesis that the principle of this type of novel is the enigma, and that this principle is rendered most visible (or rather imposed) on the plane of plot-composition" (Lasić 1973, 14, transl. MB). Underlying the constant presence of the "structural principle of the enigma" (ibid, 59), Lasić describes several types of detective plot, the form of investigation, the form of pursuit, the form of action and the form of threat, among which the latter most adequately corresponds to the situation in Noćno vijeće:

The detective novel in the form of threat can be rightfully considered an expression of a fundamental human fear: "I" is but an illusion, man is not 
more than a pawn on some vast chess-table. Exactly this notion is what the person under threat wants to negate: that he is not insane and that he is not a mere object. He is struggling to bring logic into reality. In this sense, he resembles the investigator from the investigation-form. The explanation is not simply a means of clarifying a mysterious or a dangerous act (followed by catching the criminal), but also a way to restructure the world, establish order and the rule of man. (ibid, 92)

It should be taken as indicative that the chief proponent of this subcategory of the crime genre is, according to Lasić, none other than Edgar Allan Poe, whose crime fiction was consistently blended with motifs which would later be recognised as trademarks of classic gothic fiction. Nocno vijece incorporates exactly those genre-specific motifs that are deemed indispensable, such as, for instance, the haunted house ${ }^{1}$ (the main protagonist's house) where ghosts visit the living, and this may be taken as the most obvious signal that it is a novel of the kind where the hero is compelled to "question the validity of his reasoning" (ibid, 92).

Nevertheless, if observed solely on the level of structural composition, Noćno vijeće seems to be an example of deviation from one of the key principles of the detective novel, namely the solution to the enigma, and there is an abundance of indications that this decision is made consciously and intentionally, thereby revealing the author's literary standpoint towards the ideological framework of the crime fiction genre in general. The most transparent of them is the frequency with which the appropriation of conventions of this genre occurs in Dževad Karahasan's literature, as well as the perpetual betrayal of the very same conventions in each of his novels. More simply, all of Karahasan's detective (or, rather, pseudo-detective) novels provide evidence of the author's somewhat mannerist approach to the rules of crime fiction, in the sense that all of the basic conventions and techniques of this literary genre are mastered but, at the same time, are utilised with doubt and suspicion, and that, finally, this suspicion is essentially oriented towards the above mentioned ideological framework of the crime genre, meaning its essential paradigm - that of rationality.

Given that crime fiction is one of the leading genres of our time, it is widely recognised, both in academic literary theory as well as in numerous practical manuals for writing crime fiction, that the classic detective figures, such as Agatha Christie's Hercule Poirot or Arthur Conan Doyle's Sherlock Holmes, are in fact known for their unprece-

1 In a chapter named “The Age of Smiley Tigers”, Simon's neighbour Ibrahim explains that throughout history his house had been a place where Muslim families were perpetually attacked by Serbian brigands, outlaws, and paramilitary forces. 
dented rationality, taken as a tool for solving puzzling mysteries in a manner which is impeccable and, thus, beyond ordinary human intelligence. Speaking exclusively in ideological terms, what the genre of classic crime fiction advocates is that only rationality is capable of restoring order and delivering justice. Furthermore, this "order" is perceived only in its social dimensions, as well as rationality, which is considered a human capacity per se, in a world resting upon the knowledge (or, rather, belief) that all events, consequences, and human actions can be explained and understood from the standpoint of reason alone. For the way it approaches complex human concepts such as justice, the genre of detective fiction displays a world in which both social and ethical order are established through rationality. Having rationality as its ethical core, the fundamental supposition made by this genre (and the world which it fictionally represents) is that justice derives directly from the solving of the crime, followed by exposing the perpetrator. One should recognise as well that this supposition implicates that knowledge attained through reason alone, is considered sufficient to redeem the world burdened with culpability in the eyes of victims, and, ultimately, that this genre, given its popularity and longevity since the $19^{\text {th }}$ century to this day, accurately mirrors our modern understanding of justice in each of its social manifestations.

Several essays written by the same author may serve to confirm our hypothesis that the main compositional deviation from the standard structure of the detective plot in Karahasan's Noćno vijece is a means of questioning the genre's fundamental ideological paradigm, which is to say, rationality, along with its corresponding notion of justice. This deviation occurs during one night when Simon is visited by his best friend Enver, a scholar of Islamic theology, who had spent several years searching for knowledge in the East. After the night of their first encounter, Simon is informed by the police that Enver had not only been found murdered but that he was dead even before the two of them met in his house, implicating that the main hero was visited by a ghost. In any classical detective novel, the main protagonist would make an attempt to find out who had killed his best friend (including all the earlier victims) in order to free himself from suspicion. In this case, we see Simon having no intention of pursuing the investigation any further. Instead, he goes back to his "haunted house" to meet Enver again, which will lead him to secrets that are beyond rational understanding. The result of this structural deviation is that, in the end, we are left without the knowledge of who committed the crime which, according to the basic rules of crime fiction, is unacceptable, to say the least.

Karahasan's attitude towards rationalism is spread across his entire literary oeuvre, but becomes most visible in his essay entitled Lik i njegova parodija (The Character and His Parody), where he compares Miroslav Krleža's Gospoda Glembajevi (The Glembays) with Sophocles' Oedipus, the Tyrant, while considering the latter tragedy as the oldest 
known form of detective plot in the history of Western literature and, paradoxically, as the perfect example for overcoming the structural conventions of this genre at the same time. King Oedipus, known for his infallible reasoning (as the only one among humans to have solved the enigma of the Sphinx), carries out an investigation in search for the murderer of Laius Labdacus, his father and predecessor on the throne of Thebes, only to discover that the detective and the murderer are the same person. In another essay, entitled Boravak u ogledalu (Dwelling in the Mirror) Karahasan provides what can almost be considered as a definition of melancholy as a state of being in which an excess of reason deprives one of his life: "To put it short, a melancholic is not alive. His knowledge has taken his life away from him, his reasoning has devoured his sensual experience and his ability to have such an experience" (Karahasan 2010, 74, transl. MB). In one of his stories, Anatomija tuge (The Anatomy of Sorrow) (an indirect reference to Robert Burton's Anatomy of Melancholy), Emiliano Montecchi, the main character, characterised exactly by his inability to feel, constantly suffers from cold and pneumonia, which makes him almost resemble Rene Descartes, one of the founders of western rationalist thought, who, significantly enough, died from pneumonia at the court of Queen Christina of Sweden. In a collection of various essays gathered under the title Dosadna razmatranja (Boring Discussions) Karahasan argues that the year 1609 can be considered a moment of rupture in European history for inaugurating an era of reasondominated Imago Mundi which will last to this day:

The rationalistic ambition to explain with arguments of a single sort and to understand through reasons of one kind all levels of reality and all forms of existence necessarily leads to the need to rationally resolve the apparent contradiction between the all-powerful Grace and human freedom. And the attempt to resolve this contradiction rationally leads to the conclusion that the relationship between God and Man is a sort of trade-agreement in which Man earns the Grace that God then distributes to the extent in which it is earned. In such a relationship, God would simply register Man's good deeds and efforts to earn Grace, and then these works and efforts would be rewarded adequately. This could not be reconciled with the omnipotent God, for in such a relationship God would prove man through his existence, and the relationship would have to be exactly the opposite, that is, that God should be proven through Man's existence. After all, it leads to a conclusion that Grace cannot be earned and that God is indifferent, which is contrary to every faith. (Kaharasan 1997, 29, transl. MB)

All of this serves the purpose of demonstrating that the problem of rationalism - if we may define it as such - is, in fact, one of Karahasan's major literary and philosophical 
preoccupations, and so Noćno vijeće is by no means an exception. It is also important to notice that the question, which might be formulated as what could be the best possible foundations for a perfect society, is frequently discussed throughout this novel: Mirko Landeka, the chief of police, formerly a high school teacher, introduces Simon to his theory that contemporary civilisation is utterly corrupted, first of all, by Christian morality and, secondly, by modern hedonism, "this ideology of happiness and joy" (Kaharasan 2009, 73, transl. MB). A few nights later, Simon witnesses another debate taking place in a local restaurant between two Serbian intellectuals, one of them being a communist, arguing that reason should be adopted as a fundamental principle for any morally and politically healthy society, and the other one a nationalist, opposing this position with a set of arguments that expose reason as an inevitable path to insanity. "Blessed is the nation which has good hosts instead of heroes, and good hosts are not brave but reasonable, my brothers" (ibid, 112, transl. MB) says Miloš, the communist, while Vojin, the nationalist, replies to him, according to the narrator of the story, that "the religion of exact sciences is by far the most sordid ideology ever to appear, the ideology of dead matter and economic totalitarianism, of unlimited power for those who are rich and absolute impotence, humiliation and despair for everyone else" (ibid, 116, transl. MB) and how "this religion of reason, founded upon the exact sciences, has explained to people that there is no eternity for them but to vanish in death" (ibid, transl. MB).

In chapter IX, Simon encounters Musa, his father's former comrade, and an ex-member of the communist party, whose recollections and opinions about the aftermath of World War II are filled with remorse and disappointments. In a long soliloquy, Musa admits the failures of his generation in an attempt to establish a more righteous world order, despite defeating Nazism, an ideology he deems radically opposed to the ideas of the Enlightenment. While the Nazi-regime had fallen, its fundamental idea, along with its corresponding conception of human being, had nevertheless survived and persisted throughout the $20^{\text {th }}$ century, and is undoubtedly present in the discourses that shape the way we think about ourselves and the surrounding world. This ideology, as Musa argues, was founded upon the concept that humans should be, not cultivated, but grown, and one can testify that our contemporary civilisation, although seemingly democratic and liberal, has in fact adopted this stance towards the life of the individual and that all of this is "governed by a new breed of human beings" (Kaharasan 2009, 136, transl. MB) that he likes to call "the smiley tigers":

This is something completely new in the human species, these are hybrid breeds that would probably never succeed under natural conditions but have proved very good in artificial ones. They are always smiley and welloff, they are well-paced and tactful in their behaviour, they are elegant and 
exquisitely trained, they are experts and have a good posture, they are comfortable in society and look good, they are reliable because they always reach the goal." (ibid, 137, transl. MB)

At the end of chapter X, Simon takes a moment to rest and reads a story given to him by one of the police officers that can be interpreted as a parable about the triumph of reason over all other human capacities. This story is narrated by one of the three brothers, the only one to have survived their joint venture in finding and obtaining the treasure hidden from them according to the will of their deceased father. The oldest brother was "lead by hatred" (ibid. 145, transl. MB), which made him weak, vengeful, and blind, the youngest was a "child of love" (ibid, transl. MB), thereby docile and easily influenced, and the middle one, who managed to eliminate both of them in order to obtain the treasure only for himself, was guided by reason: "Man's largest strength is his reason", concludes the narrator, "granting us with a calm sense of indifference towards anything outside the scope of our interests. I myself am living proof of this, for I am the only one of the three brothers to have survived" (ibid, 146, transl. MB).

All of these ideological perspectives ${ }^{2}$, as Boris Uspenski defines them in his most prominent study, A Poetics of Composition, are incorporated in the novel, initially, to differentiate the Weltanschauung of the characters, and at the same time, to polarise the novel's attitude towards the crisis of modernity taken as a literary topic. Additionally, the structural deviation, occurring in one of the concluding chapters of the novel, when Simon establishes that someone, probably the murderer himself (or several perpetrators in coordination), is 'setting him up', yet decides not to pursue his investigation, can be considered as another manner of subverting the rules of the crime fiction genre, and thereby the paradigm of modernity founded upon a rationalistic Imago Mundi. What Simon decides instead is to go back to his "haunted house", where he encounters Enver, and this can be interpreted as a peripeteia (Greek. $\pi \varepsilon \rho 1 \pi \dot{\varepsilon} \tau \varepsilon ı \alpha$ ), a structural turning point carrying the story further outside the boundaries of this world. It is also a point where the novel introduces one of the oldest motifs in the history of literature - the journey to the after-world. As Dante is led through hell by Virgil, here, Enver leads Simon through a place called Barzakb (Arab. برزخ), a place designating some sort of barrier or a border between worlds, or simply a place situated between, where, according to Islamic theology, the souls reside after death to dwell until the day of Qiyamah (Arab. القيامة), or The Day of Resurrection.

\footnotetext{
2 "What interests us in this case is from which point of view (in a compositional sense of the word) a certain author values and ideologically understands the world represented in his work" (Uspenski 1979, 15 , transl. MB)
} 
It would not be wrong to assume that Noćno vijece is positioning itself against the entire tradition of detective novels and the rationalistic Imago Mundi upon which this tradition relies exactly by means of resolving the story of mysterious murders in a metaphysical landscape such as the after-world of Barzakh, instead of in the setting of a police station or in court. If in a world portrayed, established, and even advocated by a detective novel, each crime that is dealt with as a rupture in the ethical order, is deemed treatable only through rational means, that is, by finding out the criminal's true identity, than a novel disobeying the rules of this genre by not revealing in the end who the murderer is can only be said to imply the following: No rupture in the ethical order of the world can be repaired and no justice can be delivered by knowing who committed the crime. Modern individual's ethical consciousness has no other option but to find this implication to be deeply provocative.

One of the most often neglected hermeneutical keys to the meaning of this novel is hidden in its very title - Noćno vijeće, i.e. The Night Council - providing enough reasons to assume that what we have here is a direct reference to an ancient philosophical dialogue written by Plato. Aside from being recognised by many authors as one of the most peculiar pieces of Plato's writings, Nónol, or The Laws, as we would call them, is also the only one of Plato's dialogues without Socrates as the main figure. Here, we have a dialogue between three men, coming from three different cities, conversing about what would be the best possible laws for a functional society. It is interesting to notice that the very notion of laws in this work of Plato differs radically from any modern secular conception of the legal state: What may seem strange from the standpoint of modern consciousness is the philosopher's insistence that the laws of any given society must be in harmony with the laws of the higher metaphysical order; as R.F. Stalley states in his Introduction to Plato's Laws, "it is not by accident that the word 'Theos', 'god' is placed emphatically at the beginning of the first sentence of The Laws" (Stalley 1983, 166). Yet, most of the peculiarities regarding The Laws are situated in Book XII, where the Athenian discusses the possibility of forming a certain institution that would have the responsibility for protecting the laws. This institution would consist of the wisest of men who would be considered the guardians of the laws (nomophylakes), and one of their tasks would be to protect society from crimes committed out of impiety. The Athenian states that if we eventually succeed in establishing this institution, admitting that this could be rather difficult to achieve, we should hand them over to the city, which means that the guardians would become an unquestionable ethical and juridical authority as well. The guardians would frequently gather to discuss fundamental questions of society and they would have an educational purpose, namely, the betterment of the ones guilty of impiety, considered to be the most fundamental of all crimes, in 
the sense that all delinquency derives from the negation of God. This institution would be a philosophical one, capable of demonstrating the fundamental truths (of Platonic philosophy) by providing a solid philosophical argument: the existence of God and the existence of the soul. Since they would convene each night from evening until the break of dawn, their name would be nukterinos sullogos, or, as we would say, The Night Council.

Leo Strauss is equally eager to notice that The Laws are "the only Platonic work which begins with 'A god”" (Strauss 1987, 85), possibly even his "most pious work”, striking "at the root of impiety, i.e., the opinion that there are no gods" (Strauss 1987, 86). That is to say since every law is of a divine origin, each crime committed is a crime against the cosmos. Moreover, one would never indulge oneself in any sort of felony without the false presumption that, for one, there is no God, two, that Gods are indifferent to the affairs of men, and three, that they can be won over by prayers and sacrifices. Therefore, the ethical institution called The Night Council protects the laws of society through its capacity to demonstrate the three fundamental truths upon which the higher metaphysical order is founded: 1) That God exists; 2) That He is not indifferent; 3) That He cannot be bribed with sacrifice nor with prayer. Or, in the words of R. F. Stalley, "law-giving is a religious task and must be grounded on an adequate theology" (Stalley 1983, 168).

Unfortunately, this is not an opportunity to thoroughly discuss all the implications that the establishment of an institution such as The Night Council would have within the legal framework of a society, given that there is in fact something contradictory about a "council of philosophically educated 'guardians" (Lewis 1998, 1) who are supposed to function as a guaranty for the rule of law and at the same time be above the rule of law, at least from the point of view of the modern secular legal state, which takes laws not as a an extension of a divine order but as a form of social agreement between equally treated citizens. It is sufficient to state, as V. B. Lewis indicates that the "centrality" of The Night Council is unavoidable "in any coherent understanding of Plato's larger political philosophy" (ibid, 2), to which the philosopher's ethical beliefs can be added, including his widely recognised stance towards atheism.

The question is, why would impiety (godlessness), that is to say, atheism be considered as the source from which all crimes originate? This is another point where similarities between Karahasan's novel, or, more precisely, the topics that are covered throughout the novel, and Plato's philosophical dialogue begin to emerge. The central issue of an atheistic Imago Mundi, at least according to Plato, seems to be the idea that justice is merely a human invention, and that the opposition between 'good' and 'evil' must be taken as ethically relative. Furthermore, "according to the Athenian", as Stalley explains, 
"the Atheists attribute most things in the universe to nature or chance" (Stalley 1983, 167), which means that human society has no solid foundation to be built on. If there is no higher metaphysical order out of which we could derive the governing principles of our society, all laws are arbitrary constructions prone to change if necessary, implicating that what is today considered morally acceptable can be rendered obsolete under different circumstances. In the words of Leo Strauss, "[i]t appears that they (The Atheists) assert that body is prior to soul or mind, or that soul or mind is derivative from the body and, consequently, that nothing is by nature just or unjust, or that all right originates in convention." (Strauss 1987, 86) If everything is conventional and thereby relative in the realm of ethics, one finds no reason to assume that what was once considered a crime cannot be deemed righteous 'under certain circumstances' and the history of the $20^{\text {th }}$ century has given us enough evidence that 'under certain circumstances' even the most vicious of crimes can be justified.

What must be more thoroughly accentuated is that Plato is a utopian thinker in pursuit of establishing, at least in theory, the ethical coordinates of a crimeless society and this is, in his opinion, possible only under a theocentric regime, where God's existence is indisputable. Although we may disagree with this opinion, what has to be noticed is that "God", considered as an ethical instance per se, corresponds to the notion of a supposed higher metaphysical order that is at the same time a guidepost for righteousness achieved in a human society. In Plato's opinion, each crime has its source in the negation that this higher ethical order, along with the idea of an 'Absolute Good', exists. From the perspective of modern man, this idea seems strange, if not even unacceptable, since our common way of understanding crime does not include the belief that murdering a human being causes an ethical disruption in the order of the cosmos. In our worldview, the notion of 'crime' has no such connotation (surprisingly enough, it is commonly not even regarded as an ethical problem, but rather as a consequence of adverse circumstances, motivated by personal interests, arising out of human fallibility taken as an ineradicable fact of nature) and therefore it is defined as a deviation from the legal order, which is, again, the only arena where it can be tackled as a problem. It may even be stated that a society functioning according to Plato's principles cannot be found in the history of mankind, but that is why we consider him an author belonging to the great tradition of utopian thinking. His anathema against moral relativism rested upon his conviction that in a Godless society crime will not only become ethically (in terms of what is considered 'good', as opposed to 'bad'), but can also become judicially (in terms of what is allowed or forbidden in a certain society) relative, since all legal boundaries become provisional and 'for the time being', and we have witnessed throughout the his- 
tory of modernity that, for example, murder can, under certain political circumstances, become not only justifiable but also a path leading towards a supposedly better society.

By choosing the 1990s era in the Balkans as a temporal framework, and by dealing with war crimes committed in the name of nationalism during this period, Noćno vijece seems to be confronting us with the reality of how legal boundaries of modern society can be disrupted in, what Giorgio Agamben calls, "the state of exception"3, when all laws are infinitely suspended. The utterly conventional nature of the legal order is what renders possible that formerly law-abiding citizens become merciless 'deliverers of justice', in their own comprehension and under different circumstances. Noćno vijeće obviously belongs to that line of critical re-evaluation of modernity, observing it as both politically and ethically unstable paradigm, always on the verge of chaos.

Taking modernity as a state of permanent crisis, Nocno vijece deals with the phenomenon of nationalism, regarding it as a symptom of rationalisation, which is, in fact, one of the interpretative lines of how this ideology came into being. While disagreeing about the exact year of birth, there seems to be a general consensus among scholars in the fields of history and sociology that both the concept of nation and the ideology of nationalism are not older than approximately two hundred years, which constitutes the essential distinction between the "perennialist" belief that nations are a somewhat "eternal continuity" and the "modernist paradigm of nations and nationalism", as it is defined by Anthony D. Smith in his Nationalism and Modernism (Smith 1998, 3). One of the first authors to shed light on the inherently modern quality of nationalism was Ernest Renan in his lecture Qu'est-ce qu'une nation? (What is a Nation?) but it was essentially Max Weber who insisted that the advent of nationalism is closely related to the process of rationalisation in modern societies: it is the "quest for statehood" (ibid, 14) that distinguishes nations from all other forms of social organisation, and according to Antony D. Smith, Weber argued that

the modern state is a rational type of association, the apogee of occidental rationalism and one of the main agencies of rationalization in history, whereas the nation is a particular type of community and prestige group. In the modern world, both need each other: the state requires the legitimation and popular direction accorded by the nation, while the nation

\footnotetext{
3 Influenced by Carl Schmitt's Political Theology, Giorgio Agamben argues that totalitarian regimes of the $20^{\text {th }}$ century such as Nazi Germany before and during World War II can be designated as "states of exception" where the legal framework of modern society, for example, its constitution, is suspended within radically changed circumstances. Agamben recognises that the "state of exception" is "not a special kind of law (like martial law), but "a suspension of the juridical order itself." (Agamben 2005, 4).
} 
needs the state to protect its unique culture values against those of other communities. (ibid)

What is also interesting to notice is that by accepting Weber's definition of both nationalism and statehood, and especially their mutual interdependence, we find ourselves again in the context of society's legal order. A modern state was, in Weber's opinion, no more-no less than a right to claim "monopoly on the legitimate use of physical force in the enforcement of its order within a given territory" (ibid, 70), and nationalism was a by-product of the necessity to establish "an administrative and legal order" able to claim "binding authority over all the citizens and actions taking place within its jurisdiction" (ibid). Or, in other words, a sense of nationality is a necessary result of a need to rationally legislate the complexity of modern society. In the absence of any other principle of unifying people in a society, the "legal-rational" (ibid) apparatus of the state becomes the central agent in providing a sense of belonging. The only thing that makes us members of the same society is that we are subject to the same laws. Although often neglected, this subtle kinship between nationality and subjection to the laws of the legal order becomes crucial in cases when society expresses the will to exclude certain ethnic, religious, or any other groups outside the scope of national identity; what follows almost immediately is the banishment outside the system of legal protection.

Now, let us examine the question of how the genre of the detective novel reflects the principles of the legal order in our modern civilisation? For one, the very genesis of the genre can be found in the concept of legality as such. An example of this is François Gayot de Pitaval (1673-1743), a French lawyer, whose famous collection of causes célèbres was often material for developing fictional plots. Another famous example is Nigel Morland (1905-1985), who was equally interested in understanding the nature of crime both fictionally, by means of a detective novel, and scientifically, through a discipline called criminology. Moreover, any analysis of the so-called roman policier can show that the legal order and crime fiction in its classic form both share our prevalent idea of how justice should be served.

This leads us back to our observation that Noćno vijeće is a novel that operates within conventions of the crime genre only to question its fundamental ideological presuppositions: As previously said, the main question posed in this case is not 'who committed the crime' but 'what can we do for the victims', or more precisely, the souls of the ones who are dead - thereby, instead of having the enigma of killings resolved, an ethical question of a different sort unexpectedly appears. To restore justice, Simon, the main protagonist of the novel, is faced with a choice presented to him by his best friend Enver, deep down in the world called Barzakh. After being exposed to such disturbing knowledge of how people who consider him as 'one of them' mercilessly tortured and 
killed people living in his house throughout history, the main hero can either leave the world of shadows, eventually forget what he saw and try to continue with his life, which means that the souls will never find their peace, or, since the shadows are immaterial beings, merely ideas wandering in this strange realm of existence, he can "kill them again by an act of thought" (Kaharasan 2007, 187, transl. MB), which is something he cannot simply do: Simon is incapable of even entertaining the thought of killing another human being. Faced with an impossible choice, Simon decides neither to kill them by an act of thought nor to forget about them; instead he makes the only decision that he can find ethically justified and in a letter addressed to his son explains that this decision is necessary "in order to break the chain" (ibid, 194): he decides to go back to Barzakh and dwell with the dead.

Assuming that certain literary forms, such as crime fiction, in this case, are in fact a reflection of our Imago Mundi, is it possible to argue that, by introducing an ethical question of this sort within the genre of detective novel, Noćno vijeće provides an alternative to our conception of justice as such? Either way, it is necessary to maintain that this history of violence, which is taken as a literary topic, in this case, offers no possibility for an ethical resolution by rational means, implicating that justice cannot be delivered within the boundaries of this world. This is the reason why another framework for the events that took place in the novel is chosen, and there are indeed numerous parallels between the realistic temporal framework in Nocno vijece and what is in theology defined as historia sacra. Let us mention only a few of them: The main hero's first name may be seen as a reference to Simon Magus (1st century A.D.), a religious figure, designated by one of the Fathers of the Christian Church as a founder of Gnosticism, the first man after Jesus to have performed miracles. Secondly, Simon's last name is Gavrilović, which can be associated with the archangel Gabriel, regarded in the biblical traditions as the angel of death who will announce the second coming of Jesus. According to the Islamic tradition, the Melek Jibreel ( taught him the Quran, meaning that he is a messenger of Allah. Furthermore, a piece of information is handed to us by the narrator that the first day of Simon's homecoming to Foča falls on 28 August, the orthodox Christian holiday called Velika Gospojina. But what is even more suggestive is the exact number of days Simon spends in Foča until leaving this world, which amounts to a total of forty days. The symbolism of this number is present in all Abrahamic religions, but especially emphasised in the Islamic tradition: It is the number of days Muhammad (a.s.) spent in a cave praying and fasting and he was also forty years old when he received the revelation; Isa (a.s.) spent forty days in the desert tempted by the devil himself, and Musa (a.s.) spent forty days on Mount Sinai where he would receive The Ten Commandments, etc. 
All of this gives rise to a conclusion that Noćno vijeće, although situated in the context of the Balkans during the 1990s, is a novel that operates within the framework of sacred history, with the main protagonist chosen by destiny to resolve an ethical problem which cannot be resolved within the sole boundaries of this world and to restore justice in a way that no modern institution can deliver it. For this reason alone, it can be said that this is a story which leaves us with a profoundly pessimistic feeling about modernity as such, and that all of our equally modern solutions to this fundamental ethical insufficiency, including the nationalist ideologies with their anti-modernist sentiments, are a path to an inevitable catastrophe.

\section{References}

Agamben, Giorgio. 2005. The State of Exception. Chicago \& London: The University of Chicago Press, 2005.

Karahasan, Dževad. 2007. Noćno vijeće. Sarajevo: Connectum.

Karahasan, Dževad. 1993. Dosadna razmatranja. Zagreb: Durieux.

Karahasan, Dževad. 2004. Dnevnik melankolije. Zenica: Vrijeme.

Karahasan, Dževad. 2010. "Boravak u ogledalu.” Sarajevske sveske no. 29/30: 63-80.

Lasić, Stanko. 1973. Poetika kriminalističkog romana. Zagreb: Mladost.

Lewis, V. Bradley. 1998. "The Nocturnal Council and Platonic Political Philosophy.” History of Political Thought 19, no. 1: 1-20. Accessed April 4, 2019. http://www.jstor.org/stable/26217450.

Smith, Anthony D. 1998. Nationalism and Modernism. London \& New York: Routledge.

Stalley, R. F. 1983. An Introduction to Plato's Laws. Oxford: Blackwell.

Strauss, Leo. 1987. "Plato.” In History of Political Philosophy, edited by Leo Strauss \& Joseph Cropsey, 33-89. Chicago \& London: The University of Chicago Press.

Uspenski, B. A. 1979. Poetika kompozicije. Semiotika ikone. Beograd: Nolit. 